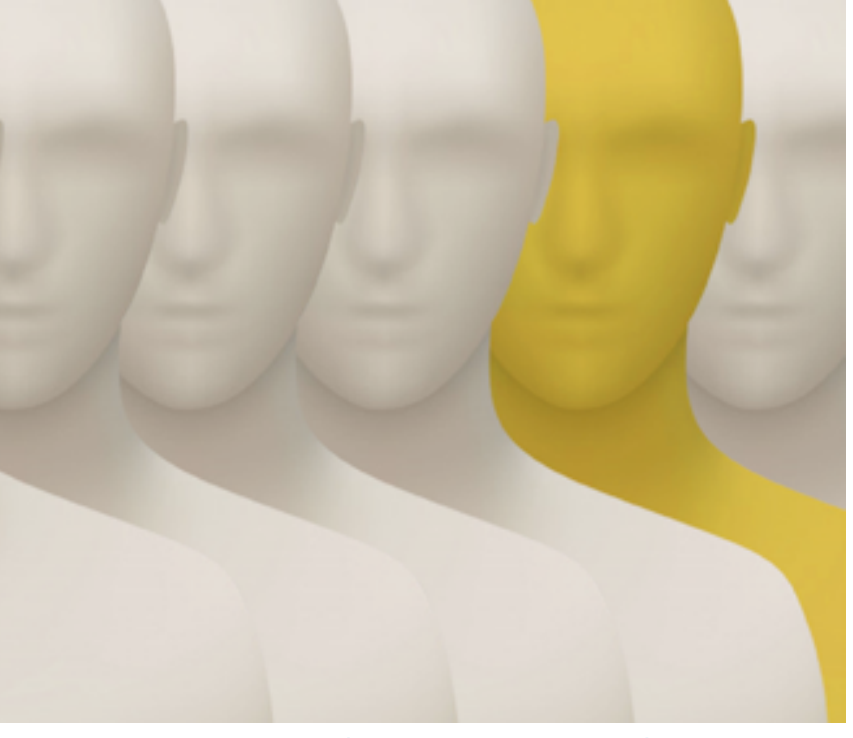

FIGURAS REVISTA ACADÉMICA DE INVESTIGACIÓN

ISSN 2683-2917

Vol. 1, núm. 1, noviembre 2019-febrero 2020

https://doi.org/10.22201/fesa.figuras.2019.1.1

Esta obra está bajo una licencia

Creative Commons Atribución-NoComercial-

Compartirlgual 4.0 Internacional

\section{Utopía y distopía en Nosotros, de Evgueni Zamiatin}

\section{Armando González Torres}

https://doi.org/10.22201/fesa.figuras.2019.1.1.89

Entre utopía y distopía hay una relación dialéctica y un delicado sistema de pesos y contrapesos narrativos, lógicos y simbólicos. Ambas son ficciones que tienen un corolario de planeación social y filosofía política. Mientras que la primera enfatiza las circunstancias en que puede perfeccionarse una sociedad y solucionar sus males; la segunda observa la forma en que ciertas tendencias sociales, aparentemente deseables, pueden desembocar en una pesadilla. Mientras que la utopía señala la disfuncionalidad de las instituciones y la posibilidad de perfeccionarlas, las distopías sugieren que lo disfuncional es la obsesión con lo perfecto. Si la utopía es optimista y constructiva, la distopía es pesimista y conservadora y, por supuesto, estos extremos gené- ricos parecen mostrar dos concepciones antropológicas radicalmente distintas. Si las utopías apuntan en mayor o menor medida a la confianza con respecto a la naturaleza del hombre, las distopías conciben al humano como un árbol que invariablemente crece torcido. La distopía, entonces, es un género gemelo, pero antagónico, de aquélla.

Si bien la distopía ha ido siempre acompañando con su sombra escéptica a la utopía, su florecimiento mayor se presentó en el siglo xx. La distopía se sitúa estratégicamente en periodos especialmente amenazadores de la libertad humana (el nacimiento del sueño totalitario en los años veinte, el ascenso del nazismo y el estalinismo, el macartismo y la guerra de Vietnam, los años de fortalecimiento del fanatismo y la Nueva Derecha durante Reagan). Para muchos distopistas del siglo pasado, la sociedad tecnológica, globalizada y totalitaria podía generar la mayor opresión, despersonalización y degradación de lo humano. Para estos autores, el progreso científico y tecnológico no constituía una promesa sino una amenaza en tanto planteaba nuevas posibilidades para las que no existía una reserva previa de inteligencia y juicios morales. De hecho, la aleación entre avance tecnológico y concentración de poder político podía empujar hacia las formas de dominación más refinadas $\mathrm{y}$, al mismo tiempo, más despiadadas que hubiera conocido la humanidad.

\section{Esta novela, escrita en 1921, fue publicada en la Europa continental, circuló en la URSS como parte de la literatura clandestina, y tuvo una enorme popularidad subterránea.}

Por su dramatismo, porque se forjó en el seno mismo de la promesa socialista y por sus imperecederas cualidades literarias, la novela Nosotros de Evgueni 
Zamiatin (1884-1938) es la decana y una de las más representativas de esta vena de denuncia. Esta novela, escrita en 1921, fue publicada en la Europa continental, circuló en la URSS como parte de la literatura clandestina, y tuvo una enorme popularidad subterránea. Nosotros es el testimonio escrito en forma de diario de un habitante del Estado único, que vive en una ciudad hipertecnologizada, hecha exclusivamente de cristal y acero. Zamiatin utiliza la parafernalia futurista de la época (cohetes aeroplanos, arquitectura funcional y cristalina, organización cronometrada de la sociedad) desplegada en un contexto totalitario. Este Estado es la materialización de una fantasía dictatorial, donde la única voluntad que priva es la del llamado "Gran Bienhechor", y a los ciudadanos se les ha extirpado el albedrío y el instinto de individualidad que siempre se subordina al de la colectividad.

\section{Con sus anacronismos y cierta ingenuidad, la anécdota de Zamiatin se convirtió en un tópico clásico de la distopía moderna (tanto que Orwell sólo reescribió el argumento para 1984).}

Los individuos, por ejemplo, se reproducen de acuerdo con criterios de eficiencia para maximizar las cualidades de los habitantes futuros, las relaciones sexuales se llevan a cabo mediante cupones rosas que reparte el Estado, siendo entonces la única ocasión en que se pueden correr las cortinas en la ciudad de cristal. La poesía se ha convertido en un arte estrictamente normado orientado a exaltar las glorias del Estado Único y todos los sentimientos antiguos, como la amistad y el amor, son considerados como el resabio de un mundo salvaje y oscuro. D-503 es un ciudadano ejemplar de esta sociedad, es ingeniero y matemático, metódico, disciplinado y eficiente trabajador, que ha construido un cohete que permitirá llevar a otros mundos el mensaje del "Gran Bienhechor". Sin embargo, la irrupción de una emoción anacrónica, el amor, que se despierta entre él y una mujer, 1-330, quien es rebelde y anhela las viejas y caducas libertades desata el drama.

La infatuación amorosa trastorna al autómata, lo aparta de sus certezas y de sus rutinas y lo hace involucionar hacia lo humano. Entre el protagonista y la elusiva heroína se establece una relación insólita, pues en principio el ciudadano modelo teme a esta mujer disoluta y disolvente que bebe alcohol clandestinamente y tiene relaciones sexuales fuera de calendario, pero al mismo tiempo queda subyugado por su misterio. Pronto, D-503 es convencido por 1-330 para participar en una conspiración. Sin embargo, el poder es omnisciente y, en un momento dado, D-503 es llamado por el Bienhechor para reprocharle su traición y su ingenuidad, pues dice que sólo fue utilizado por los conspiradores, especialmente porque él era el constructor de la nave. Al final, él será operado para recuperar su mansedumbre y su amante ejecutada. Con sus anacronismos y cierta ingenuidad, la anécdota de Zamiatin se convirtió en un tópico clásico de la distopía moderna (tanto que Orwell sólo reescribió el argumento para 1984). En la pesadilla de Zamiatin, el individuo fenece ante la figura de una autoridad bienhechora apoyada por una casta de guardianes que ejercen una extensa vigilancia, adicional a la que los propios ciudadanos ejercen entre sí (con la amenaza constante de la delación) y sobre sí mismos (con los perpetuos sentimientos de miedo, paranoia y autocensura). En este sentido, el antihéroe de Zamiatin es una delirante prefiguración del "hombre masa" dentro del totalitarismo: un ser lleno de miedo, aislado, solipsista, desconocedor de sus propias emociones y soplón permanente. -

\section{Referencia}

Zamiatin, Evgueni. Nosotros. Madrid: Hermida

Editores, 2016. 